DOI: 10.14451/2.142.15

\title{
ИДЕИ БЛАГА В ПРАВЕ
}

\author{
(c) 2020 Ланг Петр Петрович \\ кандидат юридических наук \\ Самарский государственный экономический университет, Россия, Самара \\ E-mail: petr.lang@mail.ru
}

В представленной статье рассматриваются вопросы и идеи блага в праве. Приводится эволюция категории блага в философско-правовом понимании. Анализируется практика Конституционного Суда Российской Федерации в срезе идей блага в отечественном правопорядке. Акцентируется внимание на соотношении категорий индивидуального и общего блага, особенности правового регулирования ценностного содержания. Определяются характерные черты блага как правовой категории.

Ключевые слова: благо, общее благо, аксиология, правовая ценность, иерархия правовых ценностей.

Как правило возникновение, изменение либо прекращение правоотношения обусловлено достижением желаемого позитивного результата, определенного блага.

Категория блага в свою очередь определяет качественное содержание аксиологии права, при этом не следует отождествлять схожие, но не эквивалентные понятия благо и ценность.

Как справедливо отмечает Ю.Ю.Ветютнев в одной из своих работ, посвященной аксиологии правовой формы, «ценность» хранит в себе некий экономический остаток, напоминая о цене и стоимости, а «благо» характеризуется особой возвышенностью [1].

Категория блага в современной интерпретации является результатом многовековых философских изысканий. Впоследствии посредством эволюционной трансформации рассматриваемая категория обретает правовое, юридическое звучание, обретает нормативную форму выражения и в итоге идеями блага пронизано содержание современных нормативно-правовых актов, а также актов правоприменения правоохранительных и судебных органов [2]. Данное явление отличает в том числе и отечественный, и развитые зарубежные правопорядки, определяет характеризующую особенность международного права. Что лишний раз свидетельствует об актуальности поднятого вопроса как в теоретическом, так и в практическом смыслах.

Благо в правовом значении следует рассматривать как собирательный образ ценности, общепризнанной и установленной в нормативном порядке, обеспеченной со стороны государства.

В целях наиболее основательного погружения в озвученную тему, видится методологиче- ски верным осветить историографию категории блага в философско-правовых учениях на различных этапах развития человеческого общества.

Родоначальники древнегреческой философии Платон и Аристотель неоднократно обращали свои умозрения к категории блага. Так, в частности, Платон под благом понимал интегративный социальный идеал, обуславливающий целостность общества. Единое благо Платона представляет собой определенный синтез отдельных, разрозненных благ: удовольствие, радость, разум, память и т.д. Озвученный постулат обосновывается тем, что по мнению философа, без разума невозможно постичь удовольствия, а разум без удовольствия также не приведет к достойной жизни [3].

Аристотель в свою очередь не признавал единое благо, по его утверждению благо по своей сущности многозначное явление, как и бытие. Другими словами, каждая категория бытия соответствует собственному благу. При этом Аристотель допускал функционирование в обществе иерархии благ и считал высшим из них «совершенное счастье» - созерцание [4].

Категория блага в христианскую эпоху продолжает сохранять своё унаследованное от античных мыслителей онтологическое значение. Благо проецируется на бытие и совершенство.

Яркий представитель классической немецкой философии Гегель благо исследовал в правовом аспекте, философии права и рассматривал благо как часть «моральности», как счастье.

«Удовлетворение этого содержания есть благо или счастье в их особенных определениях и во всеобщем, есть цель конкретности вообще» [5]. 
Сочетание блага и права есть синтез абстрактной формы и конкретного содержания. «Благо не имеет в этой идее значимости для себя как наличное бытие единичной особенной воли, а только как всеобщее благо и существенно как в себе всеобщее, т.е. согласно свободе; благо без права не есть добро. Так же и право не есть добро без блага (fiat justitia не должно иметь своим следствием pereat mundus). Следовательно, добро как необходимость быть действительным посредством особенной воли и вместе с тем, как ее субстанция обладает абсолютным правом по отношению к абстрактному праву собственности и особенным целям блага. Каждый из этих моментов, поскольку его отличают от добра, значим лишь в той мере, в которой он ему соответствует и подчинен» [6].

Как результат добродетельного поведения благо интерпретируется в философии В.С.Соловьева. По мнению В.С.Соловьева нравственное благо, есть добродетель в приобретенном состоянии, «норма деятельности, превратившаяся во вторую природу» [7]. В рассматриваемой плоскости любопытно привести выработанную философом дефиницию права в нравственном разрезе: «право есть принудительное требование реализации определенного минимального добра, или такого порядка, который не допускает известных крайних проявлений зла» [8].

Критикуя в целом позицию Платона о едином благе, немецкий философ Н.Гартман констатирует, что благо представляет собой организующее и упорядочивающее начало в системе ценностей. Благо - есть лежащая в телеологии самих ценностей и содержательно руководящая ценностная селекция с учетом ценностных приоритетов [9]. При этом благо, по сути, не обладает фиксированным и определенным содержанием, а является результатом личного восприятия каждого субъекта социума, совершающего конкретные действия.

Озвученное относительно категории блага свидетельствует об определенной эволюции идеи блага. При этом уместно привести совершенно оправданное мнение Ю.Ю.Ветютнева о том, что понятие блага всегда в той или иной мере сохраняет элементы своего прежнего содержания: наряду с дифференциацией ценностей оно указывает и на их интеграцию, ведь применение одного и того же понятия «благо» к различным по своей природе явлениям неизбежно означает, что все они имеют между собой нечто общее [10].

Далее предлагается осветить нормативную составляющую рассматриваемой категории. В первую очередь хотелось бы отметить, что категория блага активно ангажируется в текстах международно-правовых актах. Например, в Стокгольмской декларацией от 16.06.1972, принятой на Конференции ООН по проблемам окружающей человека среды, понятие блага встречается в пунктах 3, 7 и т.д.

Другой пример, в первом абзаце статьи 1 Договора о принципах деятельности государств по исследованию и использованию космического пространства, включая Луну и другие небесные тела (Москва - Вашингтон - Лондон, 27.01.1967) определено, что исследование и использование космического пространства, включая Луну и другие небесные тела, осуществляются на благо и в интересах всех стран, независимо от степени их экономического или научного развития, и являются достоянием всего человечества.

В приведенных примерах категория блага является связующим звеном между действительным расположением дел и целью, на достижение которой и направлен нормативно-правовой акт. При этом следует учитывать, что правовая цель представляет собой результат осознанного целенаправленного упорядочения конкретных общественных отношений посредством нормативного либо доктринального закрепления [11]. То есть для определения цели в правовом качестве нет безусловной необходимости закреплять ее в соответствующем нормативно-правовом акте с учетом телеологического толкования названной цели.

Юридическая техника международных актов традиционно предполагает, как правило нормативное закрепление целей принятого акта, что в последствии учитывается при толковании нормативных положений указанного акта, для уяснения смысла последнего.

Термин, формулировка «на благо» в текстах международно-правовых актах зачастую подразумевает всеобщее улучшение имеющегося положения у подписавших и ратифицировавших международный правовой акт (соглашение) сторон, в чем бы оно не выражалось.

В законодательстве Российской Федерации общее понятие блага отсутствует.

Результатом отсутствия единых ценностных установок является определенная противоречивость действующей правоприменитель- 
ной практики. Особенно актуальна реализация принципа учета общего блага в налоговом, гражданском, пенсионном, трудовом и земельном праве. Осмысление категории «общее благо» будет способствовать развитию института проникающей ответственности в корпоративном праве, урегулированию спорных вопросов, связанных с доступностью результатов интеллектуальной деятельности, и т.д. [12]

В отечественном правопорядке принято отличать блага на материальные и нематериальные. В частности, в статье 128 Гражданского кодекса Российской Федерации нематериальные блага названы в числе объектов гражданских прав. Само по себе понятие нематериального блага в действующем законодательстве России также отсутствует. При этом гражданское законодательство подробным образом перечисляет нематериальные блага (жизнь, здоровье, достоинство личности и мн. др.). Регулирование нематериальных благ в России характеризуется неотчуждаемостью названных благ. Другими словами, нематериальное благо нельзя передать, уступить, продать и иным образом отчудить в пользу иного лица [13].

Термин материальное благо используется в нормативной плоскости значительно реже. Например, часть 2 статьи 56 Федерального закона «Об основных гарантиях избирательных прав и права на участие в референдуме граждан Российской Федерации» запрещает кандидатам, объединениям и другим лицам при проведении агитации осуществлять подкуп избирателей, в том числе посредством обещаний передачи им денежных средств, ценных бумаг и других материальных благ.

Не смотря на отсутствие легального определения блага в отечественном правопорядке, рассматриваемая категория достаточно часто становится предметом рассмотрения в правоприменительной практике судов. Естественно, ведущую роль в формировании правовых позиций относительно общего блага, блага, правовых ценностей играет Конституционный Суд Российской Федерации.

В данной области, наиболее показательными являются правовые позиции Конституционного Суда Российской Федерации относительно толкования, восприятия, уяснения категории «общее благо», содержащиеся в постановлениях и определениях, посвященных сфере публичноправовых отношений.

В качестве иллюстрации можно привести постановление Конституционного Суда Российской Федерации от 14.07.2005 № 9-П «По делу о проверке конституционности положений статьи 113 Налогового кодекса Российской Федерации в связи с жалобой гражданки Г.А.Поляковой и запросом Федерального арбитражного суда Московского округа» в котором, Суд смещает акцент с персонального обеспечения права собственности налогоплательщика на защиту материальных благ широкого круга лиц. При этом, Суд ссылается на необходимость соблюдения и реализации «...принципов справедливости, пропорциональности, соразмерности устанавливаемой ответственности определенным конституционно значимым целям (ч. 1 ст. 19, ч. 3 ст. 55 Конституции Российской Федерации)» [14].

В рассматриваемом примере обращает на себя внимание особое мнение судьи А.Л.Кононова по рассматриваемому акту, так по мнению судьи прецедент, созданный Конституционным Судом Российской Федерации, «...искажает шкалу конституционных ценностей, поскольку баланс предполагает нивелирование, уравновешивание, равнозначность интересов отдельной личности и государства, что заведомо ставит личность в подчиненное и незащищенное положение, деформирует само понятие правового государства... беспрецедентное смещение ценностей в сторону публичных, и прежде всего государственных, интересов в пользу репрессивного характера права».

В данном случае высказанная в особом мнение позиция вызывает сомнение, поскольку не в полной мере можно считать обоснованным отождествление государственного и публичного интересов. Ранее Конституционный Суд Российской Федерации определил сущностные характеристики налогов [15]. В частности, среди прочего налоги являются необходимой экономической основой существования социального государства. Налоги - это источник доходов государства, за счет которых осуществляется социальная политика. Таким образом, деятельность государственных органов, связанная со сбором налогов, активным образом влияет на публичное благо общества, то есть направлена на соблюдение интересов всего социума, а не в субъективных интересах отдельных налогоплательщиков или только государства. Следовательно, государственные и публичные интересы в определенной степени схожи, но не эквивалентны.

Впоследствии уже в 2017 году Конституцион- 
ный Суд Российской Федерации повторил, ранее высказанную позицию относительно того, что государственное регулирование налоговых отношений основано на приоритете защиты прав и законных интересов всего общества на основе принципов справедливости, равенства и равноправия [16].

Вопрос общего блага наиболее остро стоит в гражданско-правовой сфере с публичным элементом (например, государственные или муниципальные учреждения). Сказанное обусловлено в первую очередь тем, что субъект гражданского правоотношения с административнопубличными характеристиками связан специальными функциями социального направления, то есть деятельность указанного субъекта, исходя из нормативно установленной компетенции последнего, имеет цель достижения конкретного блага. В этой связи, в правореализации не исключена конкуренция диспозитивных начал частноправовых отношений с одной стороны и публичного интереса в смысле приоритета общего блага с другой.

Роль категории блага в гражданском праве давно находится в центре внимания цивилистов. Классик отечественной юриспруденции Д.И.Мейер отмечал, что гражданские сделки хотя и касаются частных лиц, но имеют связь с общим благом [17].

У И.А.Покровского встречаем следующее, «признавая право собственности полной властью над вещью, государство в тоже самое время резервирует для себя право налагать на нее те или другие ограничения, какие оно найдет необходимым, вплоть до полной экспроприации в интересах общего блага» [18].

Схожие положения нашли свое отражение в пункте 1 статьи 242 Гражданского кодекса Российской Федерации, в соответствии с которым в случаях стихийных бедствий, аварий, эпидемий, эпизоотий и при иных обстоятельствах, носящих чрезвычайный характер, имущество в интересах общества по решению государственных органов может быть изъято у собственника в порядке и на условиях, установленных законом, с выпла- той ему стоимости имущества (реквизиция).

В качестве другого примера изъятия у собственника объекта недвижимости в благих целях могут служить положения статьи 239.2 Гражданского кодекса Российской Федерации, регулирующие отчуждение недвижимого имущества в связи с изъятием земельного участка для государственных или муниципальных нужд.

Анализируя правоприменительную практику Конституционного Суда Российской Федерации в свете поиска баланса личных, общественных и государственных интересов, П. Л. Лихтер в одной из своих работ отмечает, что в последнее время в рассматриваемой тематике все большее время уделяется правовой категории «общее благо», отдавая должное назначение конституционным гуманистическим ценностям, органы судебной власти как правило используют метод систематического (телеологического) толкования Основного Закона и не всегда признают однозначный приоритет индивидуальных интересов над общественными [19].

Итак, благо как способность удовлетворения некой потребности, признается и защищается в нормативном порядке с учетом аксиологического вектора развития отечественного правопорядка, установленного статьей 2 Конституции Российской Федерации. Именно законодательное закрепление блага, облачение его в нормативную оболочку, трансформирует благо из социальной в правовую категорию. При этом, право не может учитывать все индивидуальные вкусы и предпочтения каждого члена социума, именно по этой причине для правового регулирования свойственно наличие обобщающих социально полезных категорий, включая категорию «общего блага», которые в свою очередь в правоприменительной практике могут вступать в противоречие с индивидуальными интересами отдельных субъектов правоотношений. Подобное корреляционное взаимодействие субъективного и общественного блага демонстрирует приоритет последнего в правоприменении, тем самым формируя актуальную иерархию правовых ценностей.

\section{Библиографический список}

1. Ветютнев Ю. Ю. Аксиология правовой формы: монография. М.: Юрлитинформ, 2013. С. 102.

2. Ланг П.П.Аксиология правоприменительной практики как квинтэссенция правовой материи // Защита прав и свобод человека и гражданина: теория и практика: сборник статей участников Международной научно-практической конференции (I Международной Школы-семинара молодых ученых-юристов), г. Москва, 10 сентября 2019 г. / под ред. В. В. Казакова, К. А. Комогорцевой; Университет прокуратуры Российской Федерации; Московский финансово-юридический университет МФЮА, 2020. С. 52 
3. Платон. Сочинение. В 4 т. Т.3. Ч.1 СПб.: Изд-во С.-Петерб. ун-та; «Изд-во Олега Абышко», 2007. С. 93-95.

4. Аристотель. Никомахова этика // Сочинения. В 4 т. Т.4. М., 1983. С. 58.

5. Гегель Г.В.Ф. Философия права. М., 1990. С.166-167.

6. Гегель Г.В.Ф. Философия права. М., 1990. С.172.

7. Соловьев В.С. Оправдание добра. М. 1996. С. 125.

8. Соловьев В. С. Право и нравственность: очерки из прикладной этики. М.: Книга по требованию, 2013. С.28.

9. Гартман Н. Этика. СПб., 2002. С.304.

10. Ветютнев Ю. Ю. Аксиология правовой формы: монография. М.: Юрлитинформ, 2013. С. 105.

11. Азархин А.В. К постановке вопроса о ценностном измерении правовых целей // Актуальные проблемы правоведения. 2013. № 3. С. 4.

12. Лихтер П.Л.Правовая категория «общее благо» в интерпретации Конституционного Суда Российской Федерации // Lex russica. 2019. № 4. С.78.

13. Нестеров А. В. Правовая категория нематериальных (существующих) благ и их систематизация // Журнал российского права. 2020. № 3. С. 19-30.

14. Постановление Конституционного Суда Российской Федерации от 14.07 .2005 № 9-П «По делу о проверке конституционности положений статьи 113 Налогового кодекса Российской Федерации в связи с жалобой гражданки Г. А. Поляковой и запросом Федерального арбитражного суда Московского округа» // Вестник КС РФ. 2005. № 4.

15. Постановление Конституционного Суда Российской Федерации от 16.07.2004 № 14-П «По делу о проверке конституционности отдельных положений части второй статьи 89 Налогового кодекса Российской Федерации в связи с жалобами граждан А.Д.Егорова и Н. В. Чуева» // Вестник КС РФ. 2004. N 6.

16. Постановление Конституционного Суда Российской Федерации от 19.01.2017 № 1-П «По делу о разрешении вопроса о возможности исполнения в соответствии с Конституцией Российской Федерации Постановления Европейского Суда по правам человека от 31.07.2014 по делу «ОАО «Нефтяная компания ЮКОС» против России» в связи с запросом Министерства юстиции Российской Федерации» // Вестник КС РФ. 2017. N 2.

17. Мейер Д. И. Русское гражданское право / По испр. и доп. 8-му изд., 1902. Изд.3-е, испр. М.: Статут, 2003. С. 185.

18. Покровский И. А. Основные проблемы гражданского права. М., 2001. С. 202.

19. Лихтер П.Л.Правовая категория «общее благо» в интерпретации Конституционного Суда Российской Федерации // Lex russica. 2019. № 4. C.83. 